Article

\title{
Hydrogen Peroxide and Nitric Oxide Crosstalk Mediates Brassinosteroids Induced Cold Stress Tolerance in Medicago truncatula
}

\author{
Muhammad Arfan*, Da-Wei Zhang, Li-Juan Zou, Shi-Shuai Luo, Wen-Rong Tan, Tong Zhu and \\ Hong-Hui Lin * \\ Ministry of Education Key Laboratory for Bio-Resource and Eco-Environment, College of Life Science, \\ State Key Laboratory of Hydraulics and Mountain River Engineering, Sichuan University, Chengdu 610064, \\ China; yuanmiao1892@163.com (D.-W.Z.); ljzou66@163.com (L.-J.Z.); loss0928@sina.com (S.-S.L.); \\ wenrongtan1112@163.com (W.-R.T.); tzhu@ytu.edu.cn (T.Z.) \\ * Correspondence: 2014521230002@stu.scu.edu.cn (M.A.); hhlin@scu.edu.cn (H.-H.L.)
}

Received: 3 December 2018; Accepted: 25 December 2018; Published: 2 January 2019

\begin{abstract}
Brassinosteroids (BRs) play pivotal roles in modulating plant growth, development, and stress responses. In this study, a Medicago truncatula plant pretreated with brassinolide (BL, the most active $B R$ ), enhanced cold stress tolerance by regulating the expression of several cold-related genes and antioxidant enzymes activities. Previous studies reported that hydrogen peroxide $\left(\mathrm{H}_{2} \mathrm{O}_{2}\right)$ and nitric oxide (NO) are involved during environmental stress conditions. However, how these two signaling molecules interact with each other in BRs-induced abiotic stress tolerance remain largely unclear. BL-pretreatment induced, while brassinazole (BRZ, a specific inhibitor of BRs biosynthesis) reduced $\mathrm{H}_{2} \mathrm{O}_{2}$ and $\mathrm{NO}$ production. Further, application of dimethylthiourea (DMTU, a $\mathrm{H}_{2} \mathrm{O}_{2}$ and $\mathrm{OH}^{-}$scavenger) blocked BRs-induced $\mathrm{NO}$ production, but BRs-induced $\mathrm{H}_{2} \mathrm{O}_{2}$ generation was not sensitive to 2-phenyl-4,4,5,5-tetramethylimidazoline-1-oxyl-3-oxide (PTIO, a scavenger of NO). Moreover, pretreatment with DMTU and PTIO decreased BL-induced mitochondrial alternative oxidase (AOX) and the photosystem capacity. However, pretreatment with PTIO was found to be more effective than DMTU in reducing BRs-induced increases in $V_{\text {alt }}, V_{t}$, and $M t A O X 1$ gene expression. Similarly, BRs-induced photosystem II efficiency was found in NO dependent manner than $\mathrm{H}_{2} \mathrm{O}_{2}$. Finally, we conclude that $\mathrm{H}_{2} \mathrm{O}_{2}$ was involved in NO generation, whereas $\mathrm{NO}$ was found to be crucial in BRs-induced AOX capacity, which further contributed to the protection of the photosystem under cold stress conditions in Medicago truncatula.
\end{abstract}

Keywords: brassinosteroids; cold stress tolerance; Medicago truncatula; hydrogen peroxide; nitric oxide; AOX capacity; PSII activity

\section{Introduction}

Plants are exposed to unfavorable environmental conditions during their life cycle, which leads to a reduction in productivity. To survive in adverse conditions, plants develop several complex mechanisms [1,2]. Low-temperature is one of major abiotic stress factors affecting plant growth and production. Plant species growing in both temperate and cold zones have developed an effective mechanism to enhance their freezing tolerance [3]. Several physiological, biochemical and molecular changes occur during cold stress. These changes include accumulation of proline, glycine betaine, sugar [4], and scavenging of reactive oxygen species (ROS) [5].

Brassinosteroids (BRs) are a class of plant steroid hormone that play a diverse role in floral organ elongation, seed germination, and vascular development [6]. In addition, BRs enhance tolerance to various stresses such as temperature variability, drought, salinity, heavy metals, and pathogenic 
infections $[7,8]$. Previous studies revealed that BRs could enhance stress tolerance by regulating the expression of several genes [7,9]. For instance, BRs-induced cold stress tolerance in cucumber, mainly through regulating defense related genes [10]. Further, BRs-induced stress tolerance has been associated with alteration of malondialdehyde MDA contents and antioxidant metabolism [11].

Plant responses to environmental stresses are often linked with the accumulation of reactive oxygen species (ROS) [12]. Among several ROS, hydrogen peroxide $\left(\mathrm{H}_{2} \mathrm{O}_{2}\right)$ is considered to be the most stable molecule, which is involved in many defense related mechanisms [13]. Hydrogen peroxide $\left(\mathrm{H}_{2} \mathrm{O}_{2}\right)$ generation occurs in the cell membrane because of nicotinamide adenine dinucleotide phosphate $(\mathrm{NADPH})$ oxidase. Previously, it has been reported that respiratory burst oxidase homologues $(\mathrm{RBOH})$ genes are crucial in $\mathrm{H}_{2} \mathrm{O}_{2}$ production [14,15]. It is well established that $\mathrm{H}_{2} \mathrm{O}_{2}$ acts as a stress signal in plants [16,17]. However, non-toxic levels must be maintained in a delicate balancing between $\mathrm{H}_{2} \mathrm{O}_{2}$ production and scavenging. Furthermore, several previous reports also confirmed nitric oxide's (NO) role as an endogenous signaling molecule during abiotic stress conditions $[18,19]$. Nitrate reductase (NR) and nitric oxide synthase (NOS) have been reported as two enzymatic sources [20,21]. Moreover, non-enzymatic pathways may participate in NO production $[18,20]$. BRs role in the accumulation of NO has already been discussed [22]. Previously, several studies have demonstrated that alternative oxidase (AOX) plays an important role during environmental stress tolerance [23,24]. Also, there is much evidence available on AOX's role in scavenging mitochondrial ROS $[25,26]$. In addition, AOX involvement in the enhancement of photosystem damage has also been reported [27,28].

Legumes are considered as an important source for grain and forage. These are grown on around $15 \%$ of the earth's arable surface [29]. We selected Medicago truncatula because it serves as a model plant for molecular studies, especially for legumes. The availability of a complete genome and short life cycle distinguished it for this research purpose [30,31]. Several recent studies confirmed BRs role in abiotic stress tolerance $[7,9]$. To date, few reports in the literature have focused on the $\mathrm{H}_{2} \mathrm{O}_{2}$ and NO involvement as signaling molecules in BRs-mediated plant stress tolerance [32-34]. Therefore, we hypothesized that there might be a link between $\mathrm{H}_{2} \mathrm{O}_{2}$ and $\mathrm{NO}$ in BRs-induced abiotic stress tolerance. Here, this hypothesis was tested and our experiments results demonstrated that $\mathrm{H}_{2} \mathrm{O}_{2}$ and NO crosstalk involved in BRs-induced plant tolerance to environmental stress.

\section{Results}

\subsection{Brassinosteroids (BRs) Treatment Results in the Improvement of Cold Stress Tolerance}

To investigate the role of brassinosteroids (BRs) in cold stress tolerance, some important physiological parameters were monitored after $72 \mathrm{~h}$. Under control conditions (non-stressed), plants pretreated with brassinolide (BL) exhibited less difference in phenotypes compared to brassinazole (BRZ) or water (CK), where leaves of the BL-pretreated plants appeared better (Figure 1a). However, it was easy to distinguish the different phenotypes of all treatments under cold stress. Here, BRZ-pretreated plant leaves showed more chlorosis symptoms (yellowing of leaves) compared with BL or CK (Figure 1a). Overall, BL-pretreated plants exhibited improved phenotypes in both control and cold-acclimation (Figure 1a). Further, the reactive oxygen species (ROS) were observed in BRs-induced cold stress tolerance. Hydrogen peroxide $\left(\mathrm{H}_{2} \mathrm{O}_{2}\right)$ and the superoxide $\left(\mathrm{O}_{2}{ }^{-}\right)$anion did not accumulate much in leaves under non-stressed conditions (control). The staining sites increased in leaves after cold treatment, while more ROS were accumulated in BL-pretreated leaves than BRZ-pretreated or CK (Figure 1b). To assess the degree of damage in plants, MDA contents were investigated. BL-pretreated plants showed lower levels of MDA contents compared with BRZ-pretreated or CK plants (Figure 1c). Further, we analyzed antioxidants that protect the cell from oxidative damage by scavenging ROS. Compared to the non-stressed (control), the activities of APX, CAT, POD, and SOD were increased after treatment with cold (Figure 1d-g). The activities increased in BL-pretreated plants more than water (CK) or BRZ-pretreated plants. 
a.

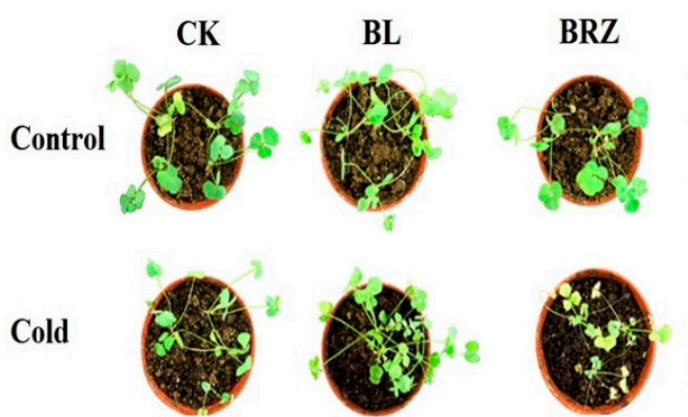

d.

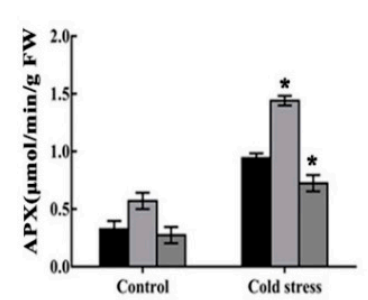

e.

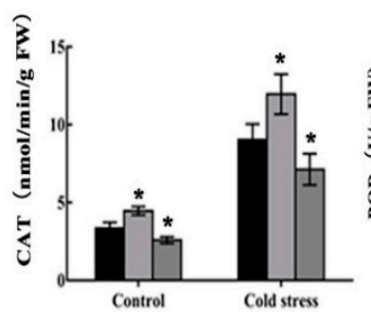

b.

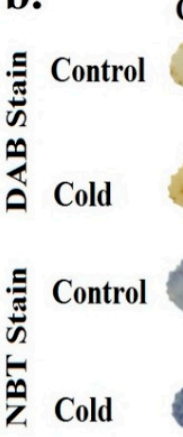

CK BL BRZ

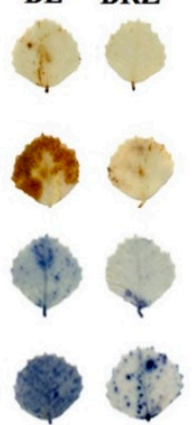

c.

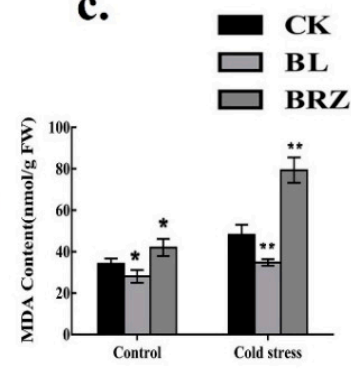

g.

Figure 1. Effects of BRs treatment on cold stress tolerance in M. truncatula plants. Plants were pretreated with $1 \mu \mathrm{M}$ BL or $1 \mu \mathrm{M}$ BRZ or water (CK) to test BRs role. Both control (non-stressed) and cold stress $\left(4{ }^{\circ} \mathrm{C}\right)$ plants' leaf tissues were collected after $72 \mathrm{~h}$ for the detection of enzymes activities and MDA contents. The cold-treated plants photographed after 3 days (a), detection of ROS sites in leaves treated with BL (b), determination of MDA contents (c), and antioxidant enzymes activities $(\mathbf{d}-\mathbf{g})$. Bars represent mean and standard deviation of values obtained from three biological replicates. Significant differences $(p<0.05)$ are denoted by asterisks.

\subsection{BRs Regulate Cold-Related Genes' Expression}

To analyze the underlying mechanisms for BRs-induced cold stress tolerance, we examined the effects of BRs levels on the expression of several genes involved in the cold-defense response. Cold-stress responsive genes targeted by dehydration-responsive element protein (DREB1)/C-repeat (CRT)-binding factor (CBF) was involved in the cold stress response. Furthermore, the expression of CAS genes was positively correlated with cold stress tolerance. Expression of 1-aminocyclopropane-1-carboxylate (ACC) synthase $(A C S)$ and ACC oxidase $(A C O)$ genes were involved in ethylene production [35]. Fatty acid desaturase (FAD) was involved in desaturation of the fatty acids. FAD genes' expression helped to understand the benefits of fatty acid desaturation in plant stress responses [36]. The expression of MtCBFs, MtP5CS1, MtCAS15, MtFAD, MtACO1, MtACS2, and MtACS7 genes were monitored. A rapid increase in transcripts of $M t C B F 1$ (Figure 2a), MtCBF2 (Figure 2b), MtCBF3 (Figure 2c), $M t C A S 15$ (Figure 2e), MtFAD (Figure 2f), MtACO1 (Figure 2g), MtACS2 (Figure 2h), and MtACS7 (Figure 2i) was observed in BL-pretreated plants after 24 and $48 \mathrm{~h}$ of cold acclimation $\left(4^{\circ} \mathrm{C}\right)$, and almost had little change in BRZ-pretreated plants compared with water-pretreated plants (CK). Under cold-acclimated conditions $\left(4^{\circ} \mathrm{C}\right)$, compared with water-pretreated plants $(\mathrm{CK})$, expression of these genes was up-regulated upon treatment with $\mathrm{BL}$, whereas they were down-regulated after BRZ treatment. Furthermore, P5CS1 was found to be involved in the control of proline levels during and after osmotic stress [37]. However, expression of MtP5CS1 in BL-pretreated plants was sustained under both control (non-stressed) and cold-stress conditions (Figure 2d). 
a.

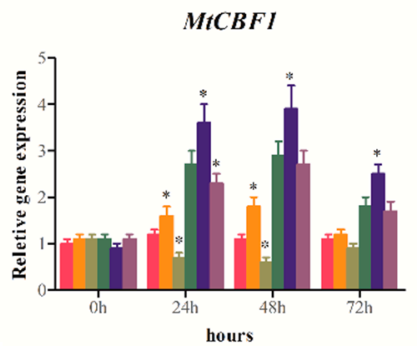

d.

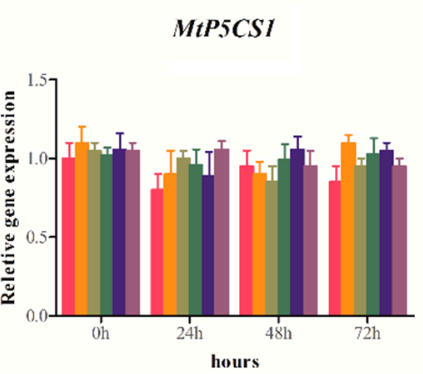

g.

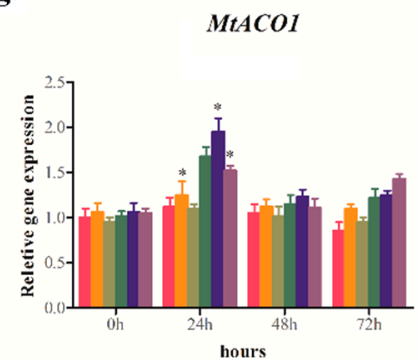

b.

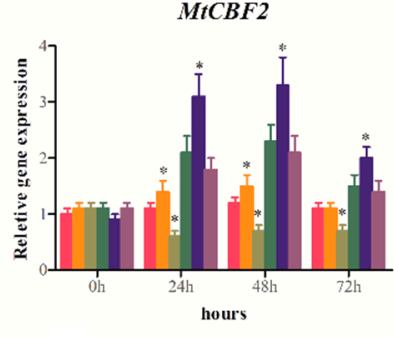

e.

MtCAS15 c.

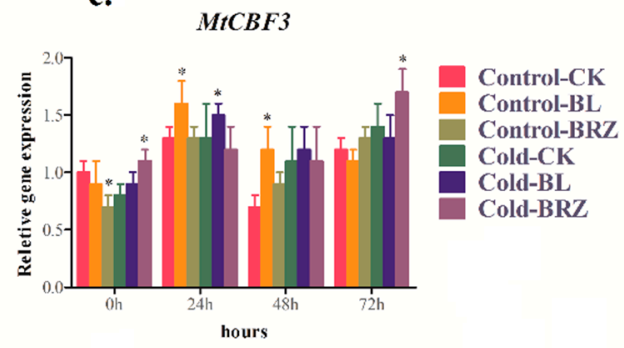

f.

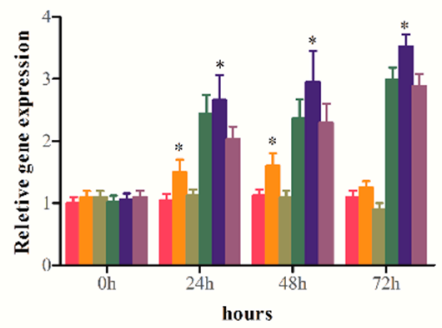

h.

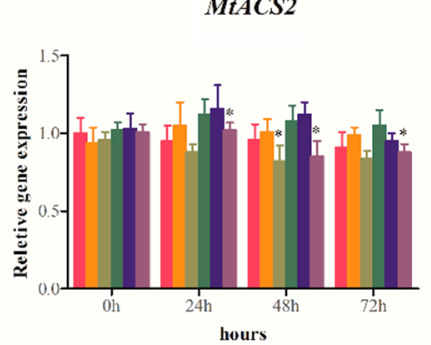

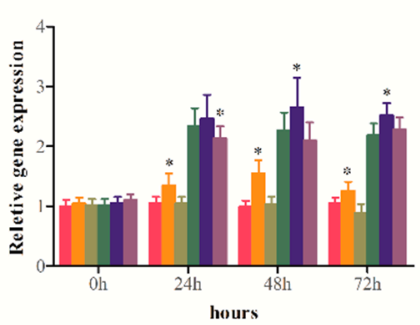

i.

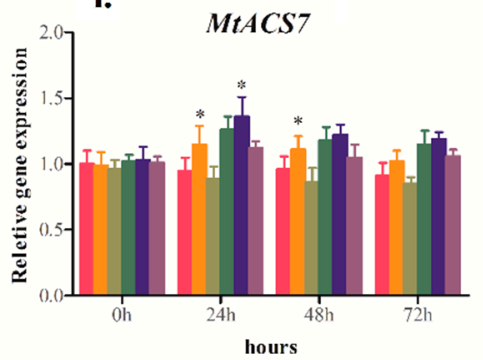

Figure 2. Response of several cold-related genes $(\mathbf{a}-\mathbf{i})$ was determined using quantitative RT-PCR. Plants were pretreated with $1 \mu \mathrm{M}$ BL or $1 \mu \mathrm{M}$ BRZ or water (CK) to investigate BRs effect. Bars represent the mean and standard deviation of values obtained from three biological replicates. Significant differences $(p<0.05)$ are denoted by asterisks.

\subsection{BRs-Treatment Induced Hydrogen Peroxide and Nitric Oxide Accumulation in Leaves}

To investigate whether BRs-induce hydrogen peroxide and nitric oxide accumulation, we detected the fluorometric assay using probe $\mathrm{H}_{2}$ DCF-DA and DAF-FM DA, respectively, with fluorescence microscope. As shown in Figure 3, pretreatment with BL accelerated both $\mathrm{H}_{2} \mathrm{O}_{2}$ and $\mathrm{NO}$ accumulation, which suggested that the significant increase of $\mathrm{H}_{2} \mathrm{O}_{2}$ and $\mathrm{NO}$ level was attributed to the BL treatment. More interestingly, after cold stress $\left(4^{\circ} \mathrm{C}\right)$ treatment, the fluorescence level increased compared to control (non-stressed) conditions. However, BL-induced $\mathrm{H}_{2} \mathrm{O}_{2}$ and $\mathrm{NO}$ accumulation was significantly higher compare to water (CK) and BRZ. Noticeably, elevated $\mathrm{H}_{2} \mathrm{O}_{2}$ and $\mathrm{NO}$ levels were observed in both control (non-stressed) and cold treatment leaves (Figure 3), suggesting that $\mathrm{H}_{2} \mathrm{O}_{2}$ and $\mathrm{NO}$ may be involved in BR-mediated cold stress tolerance.

\subsection{Relationship between BRs-Induced Hydrogen Peroxide and Nitric Oxide Accumulation}

We then investigated the potential link between $\mathrm{H}_{2} \mathrm{O}_{2}$ and $\mathrm{NO}$ in BRs-induced cold stress tolerance. Here, DMTU (a $\mathrm{H}_{2} \mathrm{O}_{2}$ and $\mathrm{OH}^{-}$scavenger) and PTIO (a scavenger of NO) were used to understand the relationship between $\mathrm{H}_{2} \mathrm{O}_{2}$ and $\mathrm{NO}$, respectively. As shown in Figure 4, pretreatment with $\mathrm{BL}$ enhanced the $\mathrm{H}_{2} \mathrm{O}_{2}$ and $\mathrm{NO}$ accumulation that could be observed by the fluorescence, while DMTU + BL and PTIO + BL scavenged the BL-induced $\mathrm{H}_{2} \mathrm{O}_{2}$ and $\mathrm{NO}$ production. Notably, pretreatment with DMTU + BL significantly declined the BL-increased NO fluorescence levels in both the control (non-stressed) and cold stress $\left(4^{\circ} \mathrm{C}\right)$ leaves. However, pretreatment with PTIO $+\mathrm{BL}$ had 
little effect on BL-induced $\mathrm{H}_{2} \mathrm{O}_{2}$ production, both in control (non-stressed) and cold stress plant leaves (Figure 4).

a.

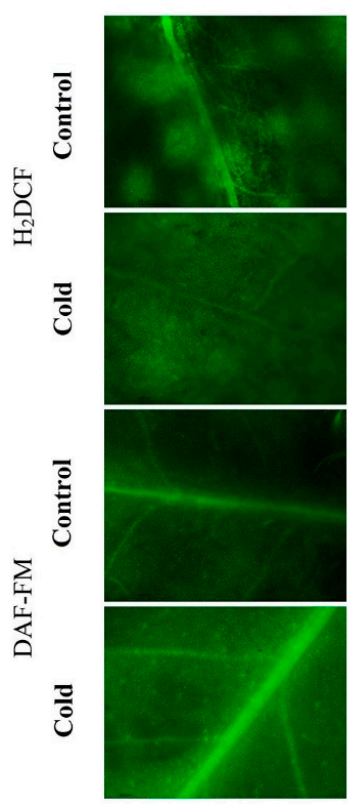

BL
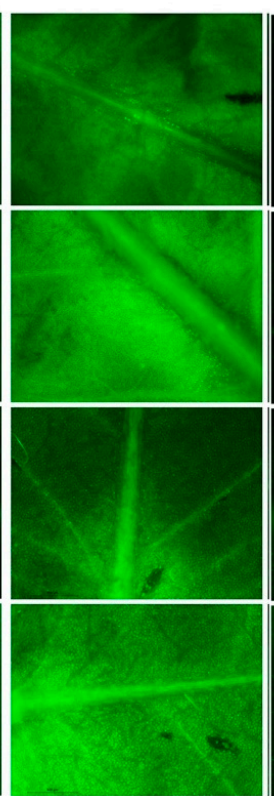

BRZ

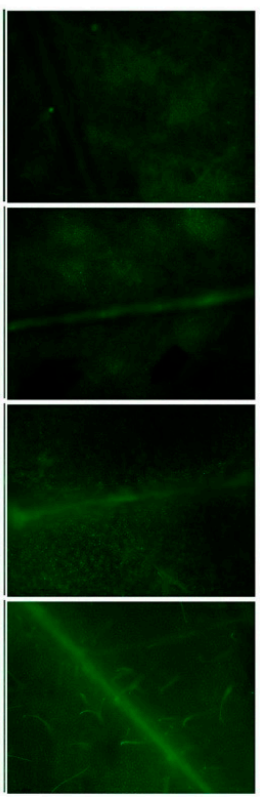

b.

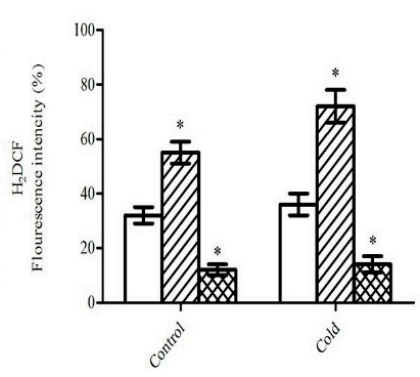

c.

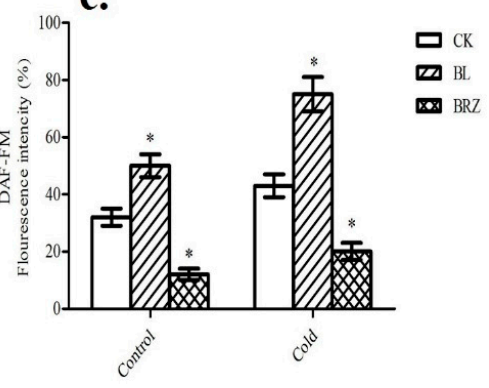

Figure 3. BRs' role in the generation of hydrogen peroxide $\left(\mathrm{H}_{2} \mathrm{O}_{2}\right)$ and nitric oxide (NO). M. truncatula plants pretreated with $1 \mu \mathrm{M}$ BL or $1 \mu \mathrm{M}$ BRZ or water (CK). Images were taken after $24 \mathrm{~h}$ of chemical treatment using a fluorescence microscope (Scale bars $=75 \mu \mathrm{m})(\mathbf{a})$. Quantitative measurements of $\mathrm{H}_{2} \mathrm{O}_{2}$ level (b) and $\mathrm{NO}$ level (c) in young leaves. Bars represent mean and standard deviation of values obtained from three biological replicates. Significant differences $(p<0.05)$ are denoted by asterisks.

a.

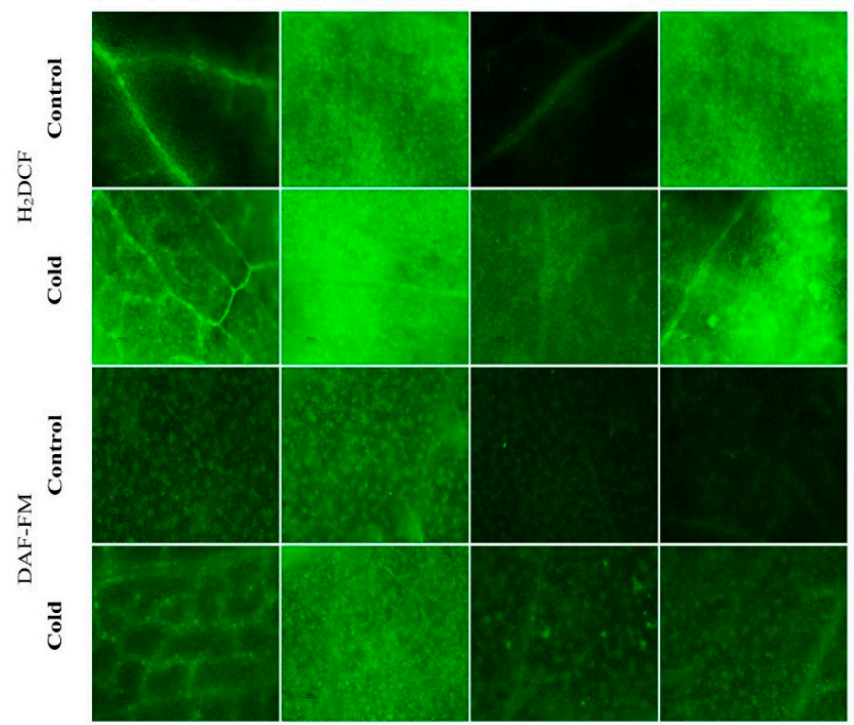

b.

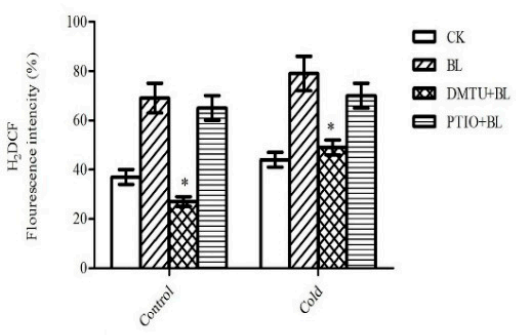

c.

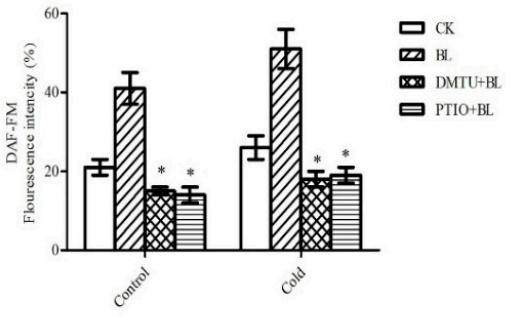

Figure 4. The relationship between BRs-induced $\mathrm{H}_{2} \mathrm{O}_{2}$ and $\mathrm{NO}$ accumulation under cold stress conditions. Images were taken after $24 \mathrm{~h}$ of chemicals treatment using a fluorescence microscope (Scale bars $=75 \mu \mathrm{m})(\mathbf{a})$. Quantitative measurements of $\mathrm{H}_{2} \mathrm{O}_{2}$ level (b) and $\mathrm{NO}$ level (c) in young leaves. Bars represent mean and standard deviation of values obtained from three biological replicates. Significant differences $(p<0.05)$ are denoted by asterisks. 


\subsection{The Role of Hydrogen Peroxide and Nitric Oxide in BRs-Induced Alternative Respiratory Pathway}

To investigate the effects of $\mathrm{BR}$-induced $\mathrm{H}_{2} \mathrm{O}_{2}$ and $\mathrm{NO}$ production on the $\mathrm{BR}$-induced alternative respiratory pathway, $M$. truncatula leaves were pretreated with DMTU $\left(\mathrm{a}_{2} \mathrm{O}_{2}\right.$ and $\mathrm{OH}^{-}$scavenger $)$ or PTIO (a scavenger of NO), and then exposed to BL treatment. Pretreatment with PTIO substantially reduced the BRs-induced increases in $V_{\text {alt }}, V_{t}$, and MtAOX1 expression, whereas pretreatment with DMTU had less of an effect on $V_{\text {alt }}, V_{t}$, and MtAOX1 expression when compared with BL-pretreated plants (Figure 5a-c).

a.

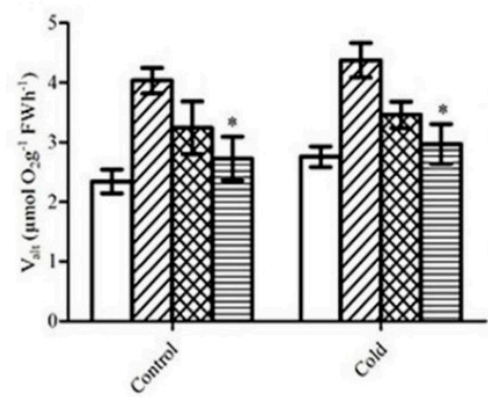

b.

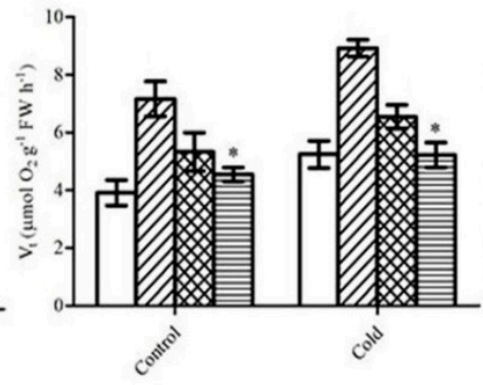

c.

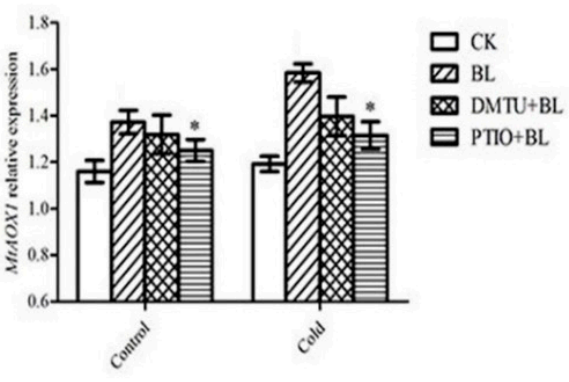

Figure 5. Effect of $\mathrm{H}_{2} \mathrm{O}_{2}$ and $\mathrm{NO}$ in BRs-induced alternative respiratory pathway. Young leaves from the same position of each plant were harvested and used for the determination of alternative respiration $\left(V_{\text {alt }}\right)(\mathbf{a})$, total respiration $\left(V_{t}\right)(\mathbf{b})$, and $M t A O X 1$ expression (c). Bars represent mean and standard deviation of values obtained from three biological replicates. Significant differences $(p<0.05)$ are denoted by asterisks.

\subsection{Hydrogen Peroxide and Nitric Oxide Involved in BRs-Induced Defense of Photosystem}

To determine whether $\mathrm{H}_{2} \mathrm{O}_{2}$ and $\mathrm{NO}$, which were induced by BRs, play a critical role in $\mathrm{BRs}$-induced cold stress tolerance, we further investigated their relationship. We analyzed the effects of DMTU $\left(\mathrm{a} \mathrm{H}_{2} \mathrm{O}_{2}\right.$ and $\mathrm{OH}^{-}$scavenger) and PTIO (a scavenger of NO) on BL-induced tolerance to cold stress. These results suggested that in the BL-pretreated plants, $F_{\mathrm{V}} / F_{\mathrm{M}}$ was higher than those in water-pretreated plants (CK) under a cold stress condition $\left(4^{\circ} \mathrm{C}\right)$; in other words, BL pretreatment alleviated the cold-induced decline of $F_{\mathrm{V}} / F_{\mathrm{M}}$. (Figure $6 \mathrm{a}, \mathrm{b}$ ). However, pretreatment with DMTU or PTIO blocked the BL-induced stress tolerance. These results showed that PTIO pretreated plants had lower $F_{\mathrm{V}} / F_{\mathrm{M}}$ than DMTU pretreated plants under cold stress conditions (Figure 6a,b). Moreover, NPQ was significantly higher in PTIO pretreated plants than those in DMTU pretreated plants under stress conditions (Figure 6c,d). 


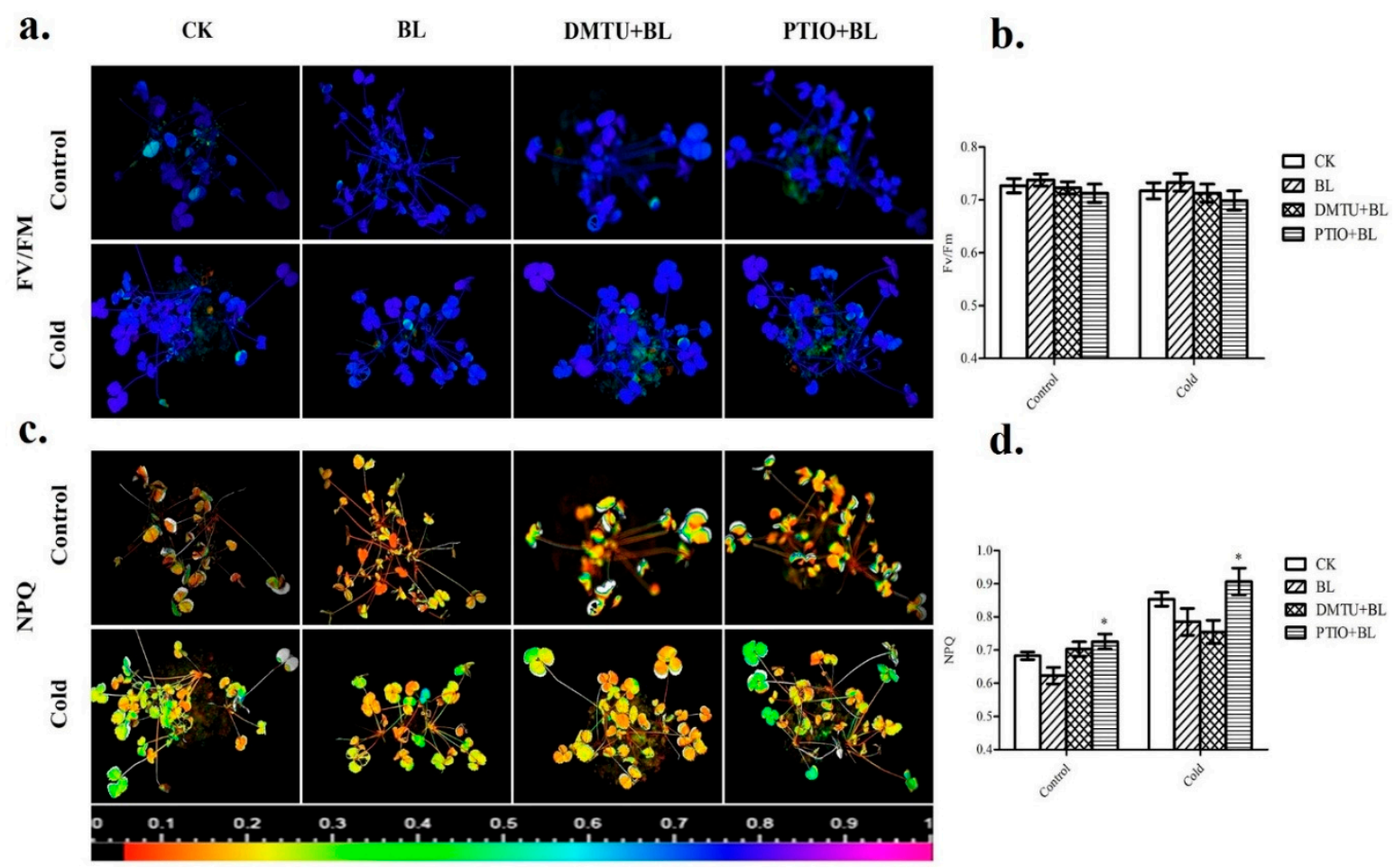

Figure 6. Chlorophyll fluorescence parameters were determined with an imaging PAM (IMAG-MAXI; HeinzWalz). Images and values of the $F_{\mathrm{V}} / F_{\mathrm{M}}(\mathbf{a}, \mathbf{b})$ and NPQ $(\mathbf{c}, \mathbf{d})$ in various treatments. The false color code depicted at the bottom of the image ranged from 0 (black) to 1.0 (purple). All the leaf samples were collected at the same time every day. Bars represent mean and standard deviation of values obtained from three biological replicates. Significant differences $(p<0.05)$ are denoted by asterisks.

\section{Discussion}

\subsection{Involvement of BRs in Cold Stress Tolerance}

Recent studies reported that BRs are involved in plant tolerance to environmental stress $[7,8]$. However, mechanisms of BR-enhanced abiotic stress tolerance remain to be determined in detail. Here, we found that BRs effectively induced physiological, biochemical, and molecular mechanisms (Figures 1 and 2). As shown in Figure 1a, the M. truncatula plant pretreated with BL demonstrated better phenotypes than water or BRZ, where more leaves turned yellow under cold stress condition (Figure 1a). ROS production during stressful environment considered as a common cellular phenomenon. Previous studies reported that ROS may act as a defense signal during a stressful environment [25,38]. Here, we found that BRs treatment enhanced ROS production of superoxide $\left(\mathrm{O}_{2}{ }^{-}\right)$anion and hydrogen peroxide $\left(\mathrm{H}_{2} \mathrm{O}_{2}\right)$, which may also involve in transferring a defense signal (Figure 1b). Moreover, BRs were found to be involved in alleviating oxidative damage. The MDA contents significantly decreased in BL-pretreated plants compared to BRZ- pretreated plants under cold stress (Figure 1c). The decline in the levels of MDA content suggests BRs mitigated the damaging effect of environmental stresses. Recent studies also showed that BRs are involved in alleviating oxidative damage $[25,39]$. Previous studies indicated that BRs enhanced the antioxidative enzymes activities [39-41]. In our study, we found that BRs elevated antioxidative enzymes activities (Figure $1 \mathrm{~d}-\mathrm{g}$ ), which may involve cold stress tolerance. In the present study, we found that BL-pretreatment significantly enhanced ROS generation (Figure 1b) and antioxidative enzymes activities (Figure 1d-g), while decreasing MDA content (Figure 1c), suggesting BRs enhanced cold stress tolerance.

Several molecular processes are altered when plants suffer from environmental stress. Here, BR-mediated enhancement of cold-related genes expression (Figure 2) may be involved in cold 
tolerance. Among them, changes in expression pattern of CBFs and COR genes are frequently involved in cold stress [7,42]. Here, BL-pretreated plants enhanced the expression of CBFs and COR genes and had little change in the BRZ-pretreated plants compared with water-pretreated plants (CK). The involvement of ethylene in response to low temperature has been reported [35,42]. Hansen et al., concluded that BRs positively influence ethylene biosynthesis through the regulation of ACC synthase $(A C S)$ and ACC oxidase (ACO) genes activity [43]. In this study, we found that ethylene regulated genes MtACO1, MtACS2, and MtACS7 were also induced in plants pretreated with BL than BRZ or water (Figure 2g-i). These results suggest that BRs may enhance cold stress tolerance by up-regulating expression of MtACO1, MtACS2, and MtACS7 genes. These observation indicated that BRs might participate in a variety of physiological functions that activate the defense system and enable plants to acquire resistance.

\subsection{BRs-Induced $\mathrm{H}_{2} \mathrm{O}_{2}$ and $\mathrm{NO}$ Generation in Medicago truncatula}

Both $\mathrm{H}_{2} \mathrm{O}_{2}$ and $\mathrm{NO}$ have been shown to play a key role in plants during environmental stresses [18]. Numerous studies have reported that $\mathrm{H}_{2} \mathrm{O}_{2}$ and $\mathrm{NO}$ production in stressful environmental conditions occur in a similar or parallel relation [44,45]. Recent studies revealed BRs role in $\mathrm{H}_{2} \mathrm{O}_{2}$ and $\mathrm{NO}$ production $[22,46,47]$. Although $\mathrm{H}_{2} \mathrm{O}_{2}$ and $\mathrm{NO}$ was found to be involved in BRs-induced stress tolerance, the relationship between these two molecules in BRs-mediated cold stress signaling remain unclear. Therefore, it was of interest to explore the relationship between these two molecules in BR-mediated cold stress tolerance. As shown in Figure 4, pretreatment with DMTU blocked BRs-induced increase in $\mathrm{H}_{2} \mathrm{O}_{2}$ levels and substantially reduced BRs-induced increase in NO levels of M. truncatula leaves. These results suggested that $\mathrm{H}_{2} \mathrm{O}_{2}$ involved in $\mathrm{BRs}$-induced $\mathrm{NO}$ generation. On the other hand, PTIO pretreated leaves could not significantly affect the increase of $\mathrm{H}_{2} \mathrm{O}_{2}$ after BRs treatment (Figure 4). The present study revealed that $\mathrm{H}_{2} \mathrm{O}_{2}$ involved in BRs-induced $\mathrm{NO}$ generation under cold stress.

\subsection{Involvement of $\mathrm{H}_{2} \mathrm{O}_{2}$ and $\mathrm{NO}$ in BRs-Induced Alternative Pathway and PSII}

The alternative oxidase (AOX) plays a crucial role in stress resistance. Previous report revealed that AOX is involved in development of freezing tolerance [16,48]. Several plant hormones, such as salicylic acid [49], Jasmonic acid [50] and ethylene [51], is found to be involved in AOX induction. In addition, another study reported that $A O X 1$ expression was enhanced by application of abscisic acid (ABA), while declined by the abi4 mutant [52]. In our study, we showed that BRs could also induce AOX, especially under cold stress condition in M. truncatula. Previously, It has been revealed that $\mathrm{H}_{2} \mathrm{O}_{2}$ and $\mathrm{NO}$ are involved in BRs-induced AOX capacity [32,34]. However, the relationship between $\mathrm{H}_{2} \mathrm{O}_{2}$ and $\mathrm{NO}$ has never been explored. In this study, we have provided evidence that pretreatment with PTIO is more effective than DMTU for the reduction of BRs-induced increase in $V_{\text {alt }}$, $V_{t}$, and MtAOX1 gene expression (Figure $5 \mathrm{a}-\mathrm{c}$ ). These results suggested that BRs-induced alternative respiratory pathway, which was more in a NO-dependent manner than $\mathrm{H}_{2} \mathrm{O}_{2}$ and may played a critical role in BL-induced cold stress tolerance.

Further, our results suggested that the enhanced AOX activity by BRs contributed to the protection of the photosystem under stress conditions (Figure 6a-d), similar to previous reports [52]. Previous findings indicated that the mitochondrial AOX pathway may be involved in the protection of plants from photosystem damage by scavenging ROS [53]. Similarly, reference [27] reported that AOX was particularly involved in alleviating photosystem damage under stress conditions. Our results indicated that BRs-induced PSII efficiency under environmental stress condition may depend on NO production more necessarily than $\mathrm{H}_{2} \mathrm{O}_{2}$ (Figure 6a-d). Thus, our results suggest that $\mathrm{NO}$ is essential in BRs-induced AOX capacity, which further contribute to the protection of the photosystem under cold stress conditions in Medicago truncatula.

In conclusion, we have revealed that $\mathrm{H}_{2} \mathrm{O}_{2}$ and $\mathrm{NO}$ are involved in the BRs-mediated cold defense signaling pathway. The possible signaling pathway for BRs-mediated cold stress tolerance 
is summarized in Figure 7. BRs enhanced the $\mathrm{H}_{2} \mathrm{O}_{2}$ and $\mathrm{NO}$ production level in M. truncatula under cold stress. Furthermore, $\mathrm{H}_{2} \mathrm{O}_{2}$ produced $\mathrm{NO}$, which plays a crucial role in the enhancement of AOX capacity. Improved AOX capacity further contributed to alleviating the photosystem damage under cold stress conditions. Furthermore, BRs-mediated signaling pathway in response to cold stress improves our understanding about plant response mechanisms to other environmental stresses.

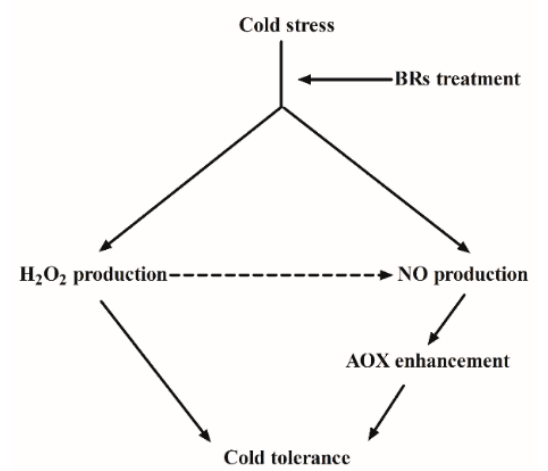

Figure 7. Model illustrating the involvement of $\mathrm{H}_{2} \mathrm{O}_{2}$ and $\mathrm{NO}$ in BRs-induced cold stress tolerance.

\section{Materials and Methods}

\subsection{Plant Material, Growth Condition, and Chemical Treatment}

The Medicago truncatula "108-R" plant was used in this cold stress experiment. First, seeds were scarified with concentrated $\mathrm{H}_{2} \mathrm{SO}_{4}$ for $5 \mathrm{~min}$ and then washed with distilled water. Later, these seeds were shifted in petri-plates on moistened filter paper at $4{ }^{\circ} \mathrm{C}$ for three nights. After germination, seedlings were transplanted into pots containing perlite and sand (3:1). The plants were grown in a greenhouse under controlled conditions at $25^{\circ} \mathrm{C}$ with a 16-h-light/8-h-dark cycle $\left(100 \mu \mathrm{mol} \cdot \mathrm{m}^{-2} \cdot \mathrm{S}^{-1}\right)$. The seedlings used in the experiments were 4 weeks old. Brassinolide (BL, the most active BRs) and brassinazole (BRZ, a specific inhibitor of BRs biosynthesis) were purchased from Wako Pure Chemical Industries (http:/ / www.wakochem.co.jp/english) and Santa Cruz Biotechnology (http:/ / www.scbt.com), respectively. Dimethylthiourea (DMTU, a $\mathrm{H}_{2} \mathrm{O}_{2}$ and $\mathrm{OH}^{-}$scavenger) and 2-phenyl-4,4,5,5-tetramethylimidazoline-1-oxyl-3-oxide (PTIO, a scavenger of NO) were purchased from Sigma-Aldrich (http:/ / www.sigmaaldrich.com). The chemical solutions were prepared in water containing $0.02 \% v / v$ Tween 20. Following three different groups of treatments were used to manipulate BRs level in M. truncatula: Brassinolide (BL), brassinazole (BRZ), and CK (water). For chemical treatment, plants were pretreated using foliar spraying with $1 \mu \mathrm{M}$ BL or $1 \mu \mathrm{M}$ BRZ. Distilled water containing $0.02 \%(v / v)$ Tween 20 was used as a CK treatment. To investigate the role of $\mathrm{H}_{2} \mathrm{O}_{2}$ and NO in BL-induced cold stress tolerance DMTU + BL and PTIO + BL were used, respectively. First plants were pretreated with $5 \mathrm{mM}$ DMTU or $200 \mu \mathrm{M}$ PTIO and $8 \mathrm{~h}$ after pretreatment, then the plants were sprayed with $1 \mu \mathrm{M}$ BL for another $16 \mathrm{~h}$. The plants were then exposed to cold stress $\left(4^{\circ} \mathrm{C}\right)$ at $24 \mathrm{~h}$ after the chemical treatment. This method was adopted from previous research [32], with some modifications.

\subsection{Quantification of Superoxide $\left(\mathrm{O}_{2}^{-}\right)$Anion, Hydrogen Peroxide $\left(\mathrm{H}_{2} \mathrm{O}_{2}\right)$, and Malondialdehyde (MDA)}

ROS, such as superoxide and hydrogen peroxide, accumulation sites were visualized in 4-week-old plants using traditional staining techniques. The accumulation of superoxide anion and hydrogen peroxide determined using nitroblue tetrazolium (NBT) and 3,3'-diaminobenzidine (DAB) stains, respectively [24]. M. truncatula leaves were first excised at the base with a razor blade and then vacuum infiltrated in solutions with NBT $\left(0.5 \mathrm{mg} \cdot \mathrm{mL}^{-1}\right)$ for $3 \mathrm{~h}$ or DAB $\left(2 \mathrm{mg} \cdot \mathrm{mL}^{-1}\right)$ for $12 \mathrm{~h}$. Leaves were then decolorized in boiling ethanol (95\%) for $30 \mathrm{~min}$. At least five single leaves were used for each staining treatment. 
The first fresh trifoliate leaves were collected to measure lipid peroxidation. The contents of MDA were measured following the manufacturer instructions (Comin Biotechnology Co., Ltd. Suzhou, China). The level of lipid peroxidation was checked using a malondialdehyde (MDA) content assay kit (Comin Biotechnology Co., Ltd. Suzhou, China), following the manufacturer instructions. The principle was based on the thiobarbituric acid (TBA) method [54]. The absorbance of the supernatant was recorded at 532 and $600 \mathrm{~nm}$. The MDA content was calculated using the following formula: MDA content $(\mathrm{nmol} / \mathrm{g} F \mathrm{~F})=25.8 \times \Delta \mathrm{A} \div \mathrm{W}\left(\mathrm{W}\right.$ : fresh weight of sample; $\left.\Delta \mathrm{A}: \mathrm{A}_{532}-\mathrm{A}_{600}\right)$.

\subsection{Determination of Antioxidant Enzymes Activities}

The first fresh trifoliate leaves were detached to measure enzymes activities. The activities of APX, CAT, POD, and SOD were measured following the manufacturer instructions (Comin Biotechnology Co., Ltd. Suzhou, China).

Ascorbate peroxidase (APX) activity was determined based on monitoring the decrease in absorbance at $290 \mathrm{~nm}$ as ASA was oxidized [55]. The absorbance change of reaction mixture was measured at $290 \mathrm{~nm}$ for $10 \mathrm{~s}$ and $130 \mathrm{~s}$, denoted by A1 and A2, respectively. One unit was defined as the oxidation of $1 \mu \mathrm{mol}$ ASA in the reaction system per gram fresh weight per minute. CAT activity was calculated using the following formula: APX activity $(\mu \mathrm{mol} / \mathrm{min} / \mathrm{g} F W)=1.79 \times \Delta \mathrm{A} \div \mathrm{W}$ (W: fresh weight of sample, $\mathrm{g} ; \Delta \mathrm{A}=\mathrm{A}_{1}-\mathrm{A}_{2}$ ).

The catalase (CAT) activity was determined based on monitoring the absorbance of $\mathrm{H}_{2} \mathrm{O}_{2}$ at $240 \mathrm{~nm}$ [56]. The absorbance change of the reaction mixture was measured at $240 \mathrm{~nm}$ for $10 \mathrm{~s}$ and $70 \mathrm{~s}$, denoted by A1 and A2, respectively. One unit was defined as the degradation of $1 \mathrm{nmol} \mathrm{H}_{2} \mathrm{O}_{2}$ in the reaction system per gram fresh weight per minute. The CAT activity was calculated using the following formula: CAT activity $(\mathrm{nmol} / \mathrm{min} / \mathrm{g} \mathrm{FW})=678 \times \Delta \mathrm{A} \div \mathrm{W}$ (W: fresh weight of sample, $\mathrm{g}$; $\left.\Delta \mathrm{A}=\mathrm{A}_{1}-\mathrm{A}_{2}\right)$.

The peroxidase (POD) activity was determined based on the guaiacol method [57], following the manufacturer's protocol. The reaction mixture absorbance change was measured at $470 \mathrm{~nm}$ for $30 \mathrm{~s}$ and $90 \mathrm{~s}$, which were denoted as A1 and A2, respectively. One POD activity unit was defined as the increase of 0.01 of record absorbance in a $1 \mathrm{~mL}$ reaction system per gram fresh weight per minute. The POD activity was calculated according to the following formula: POD activity (U/g FW) $=7133 \times$ $\Delta \mathrm{A} \div \mathrm{W}$ (W: fresh weight of sample, $\mathrm{g} ; \Delta \mathrm{A}=\mathrm{A}_{2}-\mathrm{A}_{1}$ ).

The superoxide dismutase (SOD) activity was determined using xanthine and xanthine oxidase (XO) to generate $\mathrm{O}_{2}{ }^{-}$, which reacts with (2-(4-iodophenyl-3-(4-nitrophenyl)-5-phenyltetrazolium; INT) to form a red azan dye. The SOD activities were recognized by calculating the percentage of inhibition [57]. The absorbance was measured at $560 \mathrm{~nm}$ using a spectrophotometer (Thermo Scientific Multiskan GO). The percentage of inhibition was calculated $=[\mathrm{A}$ (control) $-\mathrm{A}$ (experiment) $] \div[\mathrm{A}$ (control) $] \times 100 \%$. The percentage of inhibition of $50 \%$ in the reaction system was defined as one unit. Finally, the SOD activity was calculated using the following formula: SOD activity (U/g FW) $=11.4 \times$ percentage of inhibition $\div(1-$ percentage of inhibition $) \div \mathrm{W} \times \mathrm{dr}(\mathrm{W}$ : fresh weight of sample, $\mathrm{g}$; $\mathrm{dr}$ : dilution ratio).

\subsection{Measurement of Endogenous $\mathrm{H}_{2} \mathrm{O}_{2}$ and $\mathrm{NO}$}

For fluorescence microscopy, $\mathrm{NO}$ and $\mathrm{H}_{2} \mathrm{O}_{2}$ were visualized using Diaminofluorescein-FM diacetate (DAF-FM-DA) and $2^{\prime}, 7^{\prime}$-dichlorofluorescein diacetate $\left(\mathrm{H}_{2}\right.$ DCF-DA) probes, respectively (Sigma-Aldrich). Briefly, leaf dices were first loaded with $15 \mu \mathrm{M}$ DAF-FM-DA for $30 \mathrm{~min}$ or $50 \mu \mathrm{M}$ $\mathrm{H}_{2}$ DCF-DA for $10 \mathrm{~min}$ in Tris/ $\mathrm{KCl}$ loading buffer ( $\mathrm{pH}$ 7.2). The process was performed in darkness at $25^{\circ} \mathrm{C}$. Further, leaves were washed three times ( 5 min each) using Tris $/ \mathrm{KCl}$ loading buffer $(10 \mathrm{mM}$ Tris and $50 \mathrm{mM} \mathrm{KCl}, \mathrm{pH} 7.2$ ), and visualized under a TE2000-U fluorescence microscope (490 nm excitation; $515 \mathrm{~nm}$ emission) (Nikon, Tokyo, Japan). Treatments were repeated at least five times. $\mathrm{NO}$ and $\mathrm{H}_{2} \mathrm{O}_{2}$ contents were also detected using a Griess reagent (Sigma-Aldrich) and an Amplex red hydrogen peroxide/peroxidase assay kit (Invitrogen), respectively [33]. 


\subsection{Respiration Measurements}

Respiratory oxygen consumption was measured using Clark-type electrodes (Hansatech, King's Lynn, U.K.), according to Xu et al., (2012) after $24 \mathrm{~h}$ of cold stress. Around $0.05 \mathrm{~g}$ of young single leaves were first cut into small pieces, and then pretreated with $5 \mathrm{~mL}$ deionized water for $15 \mathrm{~min}$ in order to eliminate wound induced respiration. These measurements were performed at $25^{\circ} \mathrm{C}$ in $2 \mathrm{~mL}$ (final volume) of phosphate buffer ( $\mathrm{pH}$ 6.8), and the cuvette was tightly closed to prevent diffusion of oxygen from the air. Inhibitors of the cytochrome pathway $(1 \mathrm{mM} \mathrm{KCN})$ and the alternative pathway $(0.5 \mathrm{mM}$ n-propyl gallate, nPG) were used. The total respiration $\left(V_{t}\right)$ was defined as the $\mathrm{O}_{2}$ uptake rate by $M$. truncatula leaves without any inhibitor. Then, $1 \mathrm{mM} \mathrm{KCN}$ was added to obtain the $\mathrm{O}_{2}$ uptake rate, defined as $V_{0}$. The residual respiration $\left(V_{\text {res }}\right)$ was estimated by measuring the rate of oxygen uptake in the presence of both $1 \mathrm{mM} \mathrm{KCN}$ and $0.5 \mathrm{mM} \mathrm{nPG}$. The individual capacity of the cytochrome pathway $\left(V_{c y t}\right)$ and the alternative pathway $\left(V_{\text {alt }}\right)$ was calculated using the following formulas: $V_{c y t}=V t-$ $V_{0} ; V_{\text {alt }}=V_{0}-V_{\text {res }}$. The $V_{\text {res }}$ in our experiment was always low and was negligible relative to other respirations. Therefore, the $V_{\text {res }}$ was not shown [34].

\subsection{Chlorophyll Fluorescence Analysis}

In this experiment, an imaging pulse amplitude modulated (PAM) fluorometer (IMAG-MINI; Heinz Walz, Effeltrich, Germany) was used to determine chlorophyll fluorescence. For the measurement of the maximal quantum efficiency of photosystem II $\left(F_{\mathrm{V}} / F_{\mathrm{M}}\right)$, plants were first dark-adapted for $30 \mathrm{~min}$. Minimal fluorescence $\left(F_{0}\right)$ was measured during the weak measuring pulses and maximal fluorescence $\left(F_{\mathrm{M}}\right)$ was measured using a $0.8 \mathrm{~s}$ pulse light at about $4000 \mu \mathrm{mol} \cdot \mathrm{m}^{-2} \cdot \mathrm{s}^{-1}$. An actinic light source was then applied to obtain steady-state fluorescence yield $\left(F_{S}\right)$, after which a second saturation pulse was applied for $0.7 \mathrm{~s}$ to obtain a light-adapted maximum fluorescence $\left(F_{\mathrm{M}}{ }^{\prime}\right)$. The $F_{\mathrm{V}} / F_{\mathrm{M}}$ and NPQ/4 were calculated as $\left(F_{\mathrm{M}}-F_{0}\right) / F_{\mathrm{M}}$ and $\left(F_{\mathrm{M}}-F_{\mathrm{M}}{ }^{\prime}\right) / F_{\mathrm{M}^{\prime}}{ }^{\prime}$, respectively $[58,59]$.

\subsection{RNA Extraction and Quantitative Real-Time PCR (qRT-PCR) Analysis}

In this experiment, total RNA was extracted from the first fresh trifoliate leaves according to previously described method [60], with some modifications. The cDNA was amplified using a SYBR Premix Ex Taq (TaKaRa Bio Inc., Dalian, China). All genes expression level was measured by quantitative real time PCR (qRT-PCR). The threshold cycle $\left(C_{t}\right)$ was defined as the PCR cycle at which a statistically significant increase in reporter fluorescence was first detected, and it was used as a measure for the starting copy numbers of the target gene. MtActin gene was used as an internal control. At least three biological replicates were performed for each sample, and three technical replicates were analyzed for each biological replicate. The primers used are listed in Table S1.

\subsection{Statistical Analysis}

Data from experiments with three or more mean values were statistically analyzed using one way ANOVA. The difference was considered to be statistically significant at $p<0.05$.

Supplementary Materials: Supplementary materials can be found at http:/ / www.mdpi.com/1422-0067/20/1/ $144 /$ s1.

Author Contributions: M.A. was mainly responsible for conceptualization, investigation, methodology, and original draft preparation. L.-J.Z., S.-S.L., W.-R.T., and T.Z. were involved in formal analysis, software, and methodology. H.-H.L. and D.-W.Z. were responsible for the funding acquisition, project administration, supervision, and writing reviews. All authors contributed to revisions and completion of the manuscript.

Funding: The research is supported by the National Natural Science Foundation of China $(31570237,31470342$, 31400211, and 31670235); the National Basic Research Program of China 973 Program (2015CB150100); and the Development Project of Transgenic Crops of China (2016ZX08009-003-002).

Acknowledgments: We are very grateful for the technical assistance provided by other members of our lab.

Conflicts of Interest: The authors declare no conflict of interest. 


\section{Abbreviations}

$\begin{array}{ll}\text { BRs } & \text { Brassinosteroids } \\ \text { BL } & \text { Brassinolide } \\ \text { BRZ } & \text { Brassinazole } \\ \text { DMTU } & \text { Dimethylthiourea } \\ \text { PTIO } & \text { 2-phenyl-4,4,5,5-tetramethylimidazoline-1-oxyl-3-oxide }\end{array}$

\section{References}

1. Zhang, S.; Cai, Z.; Wang, X. The primary signaling outputs of brassinosteroids are regulated by abscisic acid signaling. Proc. Natl. Acad. Sci. USA 2009, 106, 4543-4548. [CrossRef] [PubMed]

2. Ning, J.; Li, X.; Hicks, L.M.; Xiong, L. A Raf-like MAPKKK gene DSM1 mediates drought resistance through reactive oxygen species scavenging in rice. Plant Physiol. 2010, 152, 876-890. [CrossRef] [PubMed]

3. Guy, C.L. Cold acclimation and freezing stress tolerance: Role of protein metabolism. Annu. Rev. Plant Physiol. Plant Mol. Biol. 1990, 41, 187-223. [CrossRef]

4. Xin, Z.G.; Browse, J. Cold comfort farm: The acclimation of plants to freezing temperatures. Plant Cell Environ. 2000, 23, 893-902. [CrossRef]

5. Suzuki, N.; Mittler, R. Reactive oxygen species and temperature stresses: A delicate balance between signaling and destruction. Physiol. Plant. 2006, 126, 45-51. [CrossRef]

6. Sasse, J.M. Physiological actions of brassinosteroids: An update. J. Plant Growth Regul. 2003, 22, $276-288$. [CrossRef] [PubMed]

7. Kagale, S.; Divi, U.K.; Krochko, J.E.; Keller, W.A.; Krishna, P. Brassinosteroid confers tolerance in Arabidopsis thaliana and Brassica napus to a range of abiotic stresses. Planta 2007, 225, 353-364. [CrossRef]

8. Bajguz, A.; Hayat, S. Effects of brassinosteroids on the plant responses to environmental stresses. Plant Physiol. Biochem. 2009, 47,1-8. [CrossRef]

9. Cui, J.X.; Zhou, Y.H.; Ding, J.G.; Xia, X.J.; Shi, K.; Chen, S.C.; Asami, T.; Chen, Z.; Yu, J.Q. Role of nitric oxide in hydrogen peroxide dependent induction of abiotic stress tolerance by brassinosteroids in cucumber. Plant Cell Environ. 2011, 34, 347-358. [CrossRef]

10. Xia, X.J.; Huang, L.F.; Zhou, Y.H.; Mao, W.H.; Shi, K.; Wu, J.X.; Asami, T.; Chen, Z.X.; Yu, J.Q. Brassinosteroids promote photosynthesis and growth by enhancing activation of Rubisco and expression of photosynthetic genes in Cucumis sativus. Planta 2009, 230, 1185-1196. [CrossRef]

11. Xia, X.J.; Wang, Y.J.; Zhou, Y.H.; Tao, Y.; Mao, W.H.; Shi, K.; Asami, T.; Chen, Z.X.; Yu, J.Q. Reactive oxygen species are involved in brassinosteroid induced stress tolerance in cucumber. Plant Physiol. 2009, 150, 801-814. [CrossRef] [PubMed]

12. Baxter, A.; Mittler, R.; Suzuki, N. ROS as key players in plant stress signalling. J. Exp. Bot. 2013, 65, 1229-1240. [CrossRef] [PubMed]

13. Dat, J.; Vandenabeele, S.; Vranova, E.; van Montagu, M.; Inze, D.; van Breusegem, F. Dual action of the active oxygen species during plant stress responses. Cell. Mol. Life Sci. 2000, 57, 779-795. [CrossRef]

14. Agrawal, G.K.; Iwahashi, H.; Rackwal, R. Small GTPase (ROP) molecular switch for plant defense responses. FEBS Lett. 2003, 546, 173-180. [CrossRef]

15. Gilroy, S.; Suzuki, N.; Miller, G.; Choi, W.G.; Toyota, M.; Devireddy, A.R.; Mittler, R. A tidal wave of signals: Calcium and ROS at the forefront of rapid systemic signaling. Trends Plant Sci. 2014, 19, 623-630. [CrossRef] [PubMed]

16. Neill, S.J.; Desikan, R.; Hancock, J. Hydrogen peroxide signaling. Curr. Opin. Plant Biol. 2002, 5, 388-395. [CrossRef]

17. Zhou, J.; Wang, J.; Li, X.; Xia, X.J.; Zhou, Y.H.; Shi, K.; Chen, Z.; Yu, J.Q. $\mathrm{H}_{2} \mathrm{O}_{2}$ mediates the crosstalk of brassinosteroid and abscisic acid in tomato responses to heat and oxidative stresses. J. Exp. Bot. 2014, 65, 4371-4383. [CrossRef] [PubMed]

18. Neill, S.J.; Desikan, R.; Hancock, J. Nitric oxide signaling in plants. New Phytol. 2003, 159, 11-35. [CrossRef]

19. Zhao, L.Q.; Zhang, F.; Guo, J.K.; Yang, Y.L.; Li, B.B.; Zhang, L.X. Nitric oxide functions as a signal in salt resistance in the calluses from two ecotypes of reed. Plant Physiol. 2004, 134, 849-857. [CrossRef]

20. Wilson, I.D.; Neill, S.J.; Hancock, J.T. Nitric oxide synthesis and signaling in plants. Plant Cell Environ. 2008, 31, 622-631. [CrossRef] 
21. Corpas, F.J.; Barroso, J.B.; Carreras, A.; Valderrama, R.; Palma, J.M.; Leon, A.M.; Sandalio, L.M.; Rio, L.A. Constitutive arginine-dependent nitric oxide synthase activity in different organs of pea seedlings during plant development. Planta 2006, 224, 246-254. [CrossRef]

22. Shi, C.; Qi, C.; Ren, H.; Huang, A.; Hei, S.; She, X. Ethylene mediates brassinosteroid-induced stomatal closure via Ga protein-activated hydrogen peroxide and nitric oxide production in Arabidopsis. Plant J. 2015, 82, 280-301. [CrossRef] [PubMed]

23. Moore, A.L.; Albury, M.S.; Crichton, P.G.; Affourtit, C. Function of the alternative oxidase: Is it still a scavenger? Trends Plant Sci. 2002, 7, 478-481. [CrossRef]

24. Xu, F.; Zhang, D.W.; Zhu, F.; Tang, H.; Lv, X.; Cheng, J.; Xie, H.F.; Lin, H.H. A novel role for cyanide in the control of cucumber (Cucumis sativus L.) seedlings response to environmental stress. Plant Cell Environ. 2012, 35, 1983-1997. [CrossRef] [PubMed]

25. Wang, H.; Huang, J.; Liang, X.; Bi, Y. Involvement of hydrogen peroxide, calcium, and ethylene in the induction of the alternative pathway in chilling-stressed Arabidopsis callus. Planta 2012, 235, 53-67. [CrossRef]

26. Panda, S.K.; Sahoo, L.; Katsuhara, M.; Matsumoto, H. Overexpression of alternative oxidase gene confers aluminum tolerance by altering the respiratory capacity and the response to oxidative stress in tobacco cells. Mol. Biotechnol. 2013, 54, 551-563. [CrossRef] [PubMed]

27. Yoshida, K.; Watanabe, C.; Kato, Y.; Sakamoto, W.; Noguchi, K. Influence of chloroplastic photo-oxidative stress on mitochondrial alternative oxidase capacity and respiratory properties: A case study with Arabidopsis yellow variegated 2. Plant Cell Physiol. 2008, 49, 592-603. [CrossRef]

28. Zhang, D.W.; Yuan, S.; Xu, F.; Zhu, F.; Yuan, M.; Ye, H.X.; Guo, H.Q.; Lv, X.; Yin, Y.H.; Lin, H.H. Light intensity affects chlorophyll synthesis during greening process by metabolite signal from mitochondrial alternative oxidase in Arabidopsis. Plant Cell Environ. 2016, 39, 12-25. [CrossRef]

29. Graham, P.H.; Vance, C.P. Legumes: Importance and constraints to greater use. Plant Physiol. 2003, 131, 872-877. [CrossRef]

30. Barker, D.G.; Bianchi, S.; Blondon, F.; Dattee, Y.; Duc, G.; Essad, S.; Flament, P.; Gallusci, P.; Genier, G.; Guy, P.; et al. Medicago truncatula, a model plant for studying the molecular genetics of the Rhizobium-legume symbiosis. Plant Mol. Biol. Rep. 1990, 8, 40-49. [CrossRef]

31. Luo, S.S.; Sun, Y.N.; Zhou, X.; Zhu, T.; Zhu, L.S.; Arfan, M.; Zou, L.J.; Lin, H.H. Medicago truncatula genotypes Jemalong A17 and R108 show contrasting variations under drought stress. Plant Physiol. Biochem. 2016, 109, 190-198. [CrossRef] [PubMed]

32. Deng, X.G.; Zhu, T.; Zhang, D.W.; Lin, H.H. The alternative respiratory pathway is involved in brassinosteroid-induced environmental stress tolerance in Nicotiana benthamiana. J. Exp. Bot. 2015, 66, 6219-6232. [CrossRef]

33. Deng, X.G.; Zhu, T.; Zou, L.J.; Han, X.Y.; Zhou, X.; Xi, D.H.; Zhang, D.W.; Lin, H.H. Orchestration of hydrogen peroxide and nitric oxide in brassinosteroid-mediated systemic virus resistance in Nicotiana benthamiana. Plant J. 2016, 85, 478-493. [CrossRef] [PubMed]

34. Zhu, T.; Deng, X.G.; Tan, W.R.; Zhou, X.; Luo, S.S.; Han, X.Y.; Zhang, D.W.; Lin, H.H. Nitric oxide is involved in brassinosteroid-induced alternative respiratory pathway in Nicotiana benthamiana seedlings response to salt stress. Physiol. Plant. 2015, 156, 150-163. [CrossRef] [PubMed]

35. Zhao, M.; Liu, W.; Xia, X.; Wang, T.; Zhang, W.H. Cold acclimation-induced freezing tolerance of Medicago truncatula seedlings is negatively regulated by ethylene. Physiol. Plant. 2014, 152, 115-129. [CrossRef]

36. Zhang, Z.; Wei, X.; Liu, W.; Min, X.; Jin, X.; Ndayambaza, B.; Wang, Y. Genome-wide identification and expression analysis of the fatty acid desaturase genes in Medicago truncatula. Biochem. Biophys. Res. Commun. 2018, 499, 361-367. [CrossRef] [PubMed]

37. Székely, G.; Ábrahám, E.; Cséplő, Á.; Rigó, G.; Zsigmond, L.; Csiszár, J.; Ayaydin, F.; Strizhov, N.; Jásik, J.; Schmelzer, E.; et al. Duplicated P5CS genes of Arabidopsis play distinct roles in stress regulation and developmental control of proline biosynthesis. Plant J. 2008, 53, 11-28. [CrossRef]

38. Bowler, C.; Montagu, M.V.; Inzé, D. Superoxide dismutase and stress tolerance. Annu. Rev. Plant Physiol. Plant Mol. Biol. 1992, 43, 83-116. [CrossRef]

39. Aghdam, M.S.; Asghari, M.; Farmani, B.; Mohayeji, M.; Moradbeygi, H. Impact of postharvest brassinosteroids treatment on PAL activity in tomato fruit in response to chilling stress. Sci. Hort. 2012, 144, 116-120. [CrossRef] 
40. Hu, W.H.; Wu, Y.; Zeng, J.Z.; He, L.; Zeng, Q.M. Chill-induced inhibition of photosynthesis was alleviated by 24-epibrassinolide pretreatment in cucumber during chilling and subsequent recovery. Photosynthetica 2010, 48, 537-544. [CrossRef]

41. Fariduddin, Q.; Yusuf, M.; Chalkoo, S.; Hayat, S.; Ahmad, A. 28-Homobrassinolide improves growth and photosynthesis in Cucumis sativus L. through an enhanced antioxidant system in the presence of chilling stress. Photosynthetica 2011, 49, 55-64. [CrossRef]

42. Ereminaa, M.; Unterholzner, S.J.; Rathnayake, A.I.; Castellanos, M.; Khan, M.; Kugler, K.G.; May, S.T.; Mayer, K.F.X.; Rozhon, W.; Poppenberger, B. Brassinosteroids participate in the control of basal and acquired freezing tolerance of plants. Proc. Natl. Acad. Sci. USA 2016, 113, 5982-5991. [CrossRef] [PubMed]

43. Hansen, M.; Chae, H.S.; Kieber, J.J. Regulation of ACS protein stability by cytokinin and brassinosteroid. Plant J. 2009, 57, 606-614. [CrossRef] [PubMed]

44. Yoshioka, H.; Mase, K.; Yoshioka, M.; Kobayashi, M.; Asai, S. Regulatory mechanisms of nitric oxide and reactive oxygen species generation and their role in plant immunity. Nitric Oxide 2011, 25, 216-221. [CrossRef] [PubMed]

45. Qiao, W.; Li, C.; Fan, L.M. Cross-talk between nitric oxide and hydrogen peroxide in plant responses to abiotic stresses. Environ. Exp. Bot. 2014, 100, 84-93. [CrossRef]

46. Bright, J.; Desikan, R.; Hancock, J.T.; Weir, I.S.; Neill, S.J. ABA induced NO generation and stomatal closure in Arabidopsis is dependent on $\mathrm{H}_{2} \mathrm{O}_{2}$ synthesis. Plant J. 2006, 45, 113-122. [CrossRef] [PubMed]

47. Zhang, A.Y.; Jiang, M.Y.; Zhang, J.H.; Ding, H.D.; Xu, S.C.; Hu, X.L.; Tan, M.P. Nitric oxide induced by hydrogen peroxide mediates abscisic acid-induced activation of the mitogen activated protein kinase cascade involved in antioxidant defense in maize leaves. New Phytol. 2007, 175, 36-50. [CrossRef]

48. Mizuno, N.; Sugie, A.; Kobayashi, F.; Takumi, S. Mitochondrial alternative pathway is associated with development of freezing tolerance in common wheat. J. Plant Physiol. 2008, 165, 462-467. [CrossRef]

49. Matos, A.R.; Mendes, A.T.; Scotti-Campos, P.; Arrabaça, J.D. Study of the effects of salicylic acid on soybean mitochondrial lipids and respiratory properties using the alternative oxidase as a stress-reporter protein. Physiol. Plant. 2009, 137, 485-497. [CrossRef]

50. Fung, R.W.M.; Wang, C.Y.; Smith, D.L.; Gross, K.C.; Tian, M.S. MeSA and MeJA increase steady-state transcript levels of alternative oxidase and resistance against chilling injury in sweet peppers (Capsicum annuum L.). Plant Sci. 2004, 166, 711-719. [CrossRef]

51. Wang, H.; Liang, X.; Huang, J.; Zhang, D.; Lu, H.; Liu, Z.; Bi, Y. Involvement of ethylene and hydrogen peroxide in induction of alternative respiratory pathway in salt treated Arabidopsis calluses. Plant Cell Physiol. 2010, 51, 1754-1765. [CrossRef]

52. Giraud, E.; Van Aken, O.; Ho, L.H.; Whelan, J. The transcription factor ABI4 is a regulator of mitochondrial retrograde expression of ALTERNATIVE OXIDASE1a. Plant Physiol. 2009, 150, 1286-1296. [CrossRef] [PubMed]

53. Zhang, L.T.; Zhang, Z.S.; Gao, H.Y.; Xue, Z.C.; Yang, C.; Meng, X.L.; Meng, Q.W. Mitochondrial alternative oxidase pathway protects plants against photoinhibition by alleviating inhibition of the repair of photo damaged PSII through preventing formation of reactive oxygen species in RumexK-1 leaves. Physiol. Plant. 2011, 143, 396-407. [CrossRef] [PubMed]

54. Tanir, H.M.; Sener, T.; Inal, M.; Akyuz, F.; Uzuner, K.; Sivri, E. Effect of quercetine and glutathione on the level of superoxide dismutase, catalase, malonyldialdehyde, blood pressure and neonatal outcome in a rat model of pre-eclampsia induced by NG-nitro-L-arginine-methyl ester. Eur. J. Obstet. Gynecol. Reprod. Biol. 2005, 118, 190-195. [CrossRef]

55. Nakano, Y.; Asada, K. Hydrogen peroxide is scavenged by ascorbate-specific peroxidase in spinach chloroplasts. Plant Cell Physiol. 1981, 22, 867-880.

56. Wei, X.; Li, D.; Liu, G. Anti-oxidative responses of Elodea nuttallii (Planch.) H. St. John to short-term iron exposure. Plant Physiol. Bioch. 2010, 48, 873-878.

57. García-Triana, A.; Zenteno-Savínb, T.; Peregrino-Uriartea, A.B.; Yepiz-Plascenciaa, G. Hypoxia, reoxygenation and cytosolic manganese superoxide dismutase (cMnSOD) silencing in Litopenaeus vannamei: Effects on $c M n S O D$ transcripts, superox ide dismutase activity and superoxide anion production capacity. Dev. Comp. Immunol. 2010, 34, 1230-1235. [CrossRef] [PubMed]

58. Kitajima, M.; Butler, W.L. Quenching of chlorophyll fluorescence and primary photochemistry in chloroplasts by dibromothymoquinone. Biochim. Biophys. Acta 1975, 376, 105-115. [CrossRef] 
59. Bilger, W.; Björkman, O. Role of the xanthophyll cycle in photoprotection elucidated by measurements of light-induced absorbance changes, fluorescence and photosynthesis in leaves of Hedera canariensis. Photosynth. Res. 1990, 25, 173-185. [CrossRef]

60. Jian, W.; Zhang, D.W.; Zhu, F.; Wang, S.X.; Pu, X.J.; Deng, X.G.; Luo, S.S.; Lin, H.H. Alternative oxidase pathway is involved in the exogenous SNP-elevated tolerance of Medicago truncatula to salt stress. J. Plant Physiol. 2016, 193, 79-87. [CrossRef]

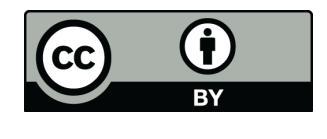

(C) 2019 by the authors. Licensee MDPI, Basel, Switzerland. This article is an open access article distributed under the terms and conditions of the Creative Commons Attribution (CC BY) license (http:/ / creativecommons.org/licenses/by/4.0/). 